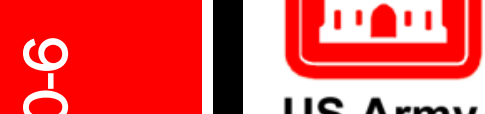

US Army Corps

of Engineers ${ }_{\circledast}$

Engineer Research and

Development Center

ERDC 6.2 Boreal Aspects of Ensured Maneuver (BAEM)

Mechanical Property Measurements on Various Snow Surfaces

S. Shoop, W. Wieder, and B. Elder

August 2020 
The U.S. Army Engineer Research and Development Center (ERDC) solves the nation's toughest engineering and environmental challenges. ERDC develops innovative solutions in civil and military engineering, geospatial sciences, water resources, and environmental sciences for the Army, the Department of Defense, civilian agencies, and our nation's public good. Find out more at www.erdc.usace.army.mil.

To search for other technical reports published by ERDC, visit the ERDC online library at https://erdclibrary.on.worldcat.org/discovery. 


\title{
Mechanical Property Measurements on Various Snow Surfaces
}

\author{
S. Shoop, W. Wieder, and B. Elder
}

U.S. Army Engineer Research and Development Center (ERDC)

Cold Regions Research and Engineering Laboratory (CRREL)

72 Lyme Road

Hanover, NH 03755-1290

Final Report

Approved for public release; distribution is unlimited.

Prepared for Assistant Secretary of the Army for Acquisition, Logistics, and Technology 103 Army Pentagon

Washington, DC 20314-1000

Under Project 465395, ERDC 6.2 “Boreal Aspects of Ensured Maneuver (BAEM)," and Project 471941, "Remote Assessment of Snow Mechanical Properties" and "Mobility in Peat and Northern Soils" 


\section{Preface}

This study was conducted for the Assistant Secretary of the Army for Acquisition, Logistics, and Technology under project number 465395, "Boreal Aspects of Ensured Maneuver (BAEM)," which is part of the U.S. Army Engineer Research and Development Center (ERDC) 6.2 Remote Assessment of Infrastructure for Ensured Maneuver (RAFTER) Program managed by Ms. Danielle Whitlow, ERDC Geotechnical and Structures Laboratory (GSL).

The work was performed by the Force Projection and Sustainment Branch (CEERD-RRH) and the Terrestrial and Cryospheric Sciences Branch (CEERD-RRG) of the Research and Engineering Division (CEERD-RR), U.S. Army Engineer Research and Development Center, Cold Regions Research and Engineering Laboratory (ERDC-CRREL). At the time of publication, Mr. Jimmy Horne was Acting Chief, CEERD-RRH; Dr. John Weatherly was Chief, CEERD-RRG; and Mr. Jimmy Horne was Chief, CEERD-RR. The Deputy Director of ERDC-CRREL was Mr. David B. Ringelberg, and the Director was Dr. Joseph L. Corriveau.

This Miscellaneous Paper (MP) was originally published in Proceedings of the 18th International Conference on Cold Regions Engineering and $8^{\text {th }}$ Canadian Permafrost Conference, 18-22 August 2019, Quebec City, Quebec, Canada, and funded under Project 471941, "Remote Assessment of Snow Mechanical Properties."

COL Teresa A. Schlosser was Commander of ERDC, and Dr. David W. Pittman was the Director.

DISCLAIMER: The contents of this report are not to be used for advertising, publication, or promotional purposes. Citation of trade names does not constitute an official endorsement or approval of the use of such commercial products. All product names and trademarks cited are the property of their respective owners. The findings of this report are not to be construed as an official Department of the Army position unless so designated by other authorized documents.

DESTROY THIS REPORT WHEN NO LONGER NEEDED. DO NOT RETURN IT TO THE ORIGINATOR. 


\begin{abstract}
During the winter of 2018 field experiments were conducted to assess the mechanical properties of virgin, groomed and compacted snow. These strength measurement techniques assessed the bearing and shear capacity of the snow, or a combination thereof. Many of the methods were adapted from those used in soil and pavement assessments and could be related to California Bearing Ratio; and others were techniques specifically designed for snow characterization (Rammsonde, Russian snow penetrometer, CTI penetrometer, Yamaha drop cone,). The results illustrate typical values and ranges for the strength of different types of snow surfaces, and the applicability or effectiveness of the different tests to specific snow conditions.
\end{abstract}

KEY WORDS: Bearing, compacted, groomed, strength, winter.

\title{
1 INTRODUCTION
}

Undisturbed, virgin snow and groomed snow surfaces vary greatly in strength. Deep, virgin snow is soft, and unable to support heavy loads that are not distributed over a large surface area. Groomed snow can support significant loads to include large wheeled commercial and military vehicles (Sopher and Shoop 2017).

As part of a larger study to assess seasonal vehicle mobility in the north, the U.S. Army Engineer Research and Development Center (ERDC) Cold Regions Research and Engineering Laboratory (CRREL) collected data on snow and ice surface strength at two sites: The Nevada Automotive Test Center's (NATC) Winter Test Facility located at the West Yellowstone Airport, West Yellowstone, Montana; and the Keweenaw Research Center (KRC), in Calumet, Michigan. Both facilities run a wide range of winter vehicle testing over winter surfaces for both military and commercial vehicles.

CRREL's work in Montana and Michigan used a variety of testing equipment to characterize snow, both in the virgin snow pack and under an assortment of groomed or trafficked snow conditions, and ice surfaces. The equipment evaluated included tests designed specifically for snow (e.g. the Rammsonde, Russian Snow Penetrometer (RSP), CTI penetrometer, and Yamaha drop cone) and equipment typically used for compacted or natural soils (e.g., the field California Bearing Ratio (CBR), Lightweight 
Deflectometer (LWD), Clegg Impact Hammer, and shear vane). This paper discusses the strength tests performed to characterize snow and ice. The snow physical property characterization techniques are discussed in Elder et al. (2019) and the profiles of depth, density, and temperature measurements the many surfaces studied are given in Shoop et al. (2019).

\section{TEST SITES}

Both test sites used in this study are large facilities with several other vehicle testing programs happening concurrently to our efforts. The groomed surfaces were prepared specifically for the vehicle testing inherent to the facility, such as roads and large open areas (pads), where breaking and other types of vehicle testing commonly occur. The virgin snow surfaces were undisturbed.

Montana: NATC maintains approximately 18.5 hectares of groomed test surfaces at the site of the West Yellowstone Airport, which is closed to air traffic in the winter. Test surfaces are maintained at medium pack (70 to $80 \mathrm{CTI})$, soft pack (50 to $70 \mathrm{CTI})$, hard pack (80 to $90 \mathrm{CTI}$ ) with virgin snow and iced surfaces also available (CTI measurements are discussed later). The snow surfaces in Montana were underlain by asphalt (i.e. runway, taxiway and apron pavements) or unsurfaced terrain.

The Montana work was conducted from 24 January to 2 February 2018. CRREL partnered with the US Marine Corps, NATC and Boise State University to perform concurrent vehicle and snow characterization along with and satellite data collections. Testing occurred during various hours, including night shifts, to preserve the snow surfaces and accommodate other test programs at the site.

Michigan: The second field campaign was completed at KRC in Calumet, Michigan from 19 to 23 February 2018. KRC is a research institute of Michigan Technological University. The site is located in the Upper Peninsula of Michigan adjacent to the Houghton Memorial Airport, seven miles north of the main Michigan Tech campus.

The test courses consisted of over 200 hectares of prepared surfaces such as handling loops, a circular track and slopes. The courses are used year round for acceleration and braking, slope climbing, noise, vibration, obstacle crossing and endurance tests. Every winter, special ice and snow areas are constructed for vehicle ride and handling studies, anti-lock brake tests and tire traction evaluations. The snow and ice surfaces were underlain by gravel, unsurfaced roads, turf and undeveloped terrain. Testing occurred during daylight hours.

\section{TEST PROGRAM}

Field testing was divided roughly into two categories: 1) "soft" snow, and 2) "hard" or groomed snow. Soft snow was accumulated virgin snow, undisturbed by vehicles or any 
other activity excluding natural weather activity (i.e. wind, sun, and precipitation). Groomed snow had been prepared by dragging, tilling, compacting, or other surface treatments as needed to obtain the desired surface for specific types of vehicle testing.

The capabilities, or range, of each particular piece of snow strength test equipment tended to fall into either the soft (virgin) snow, or hard (groomed) snow categories as listed in Sections 3.1 and 3.2. Standard snow characterization measurements, however, were applicable both to groomed and soft snow surfaces: air and snow temperatures, snow depth, and moisture and density profiles (given in Shoop et al. 2019). An additional snow strength test apparatus called the SnowMicroPenetrometer (SMP) was used at the Montana site and is documented in Meehan et al. (2019).

\subsection{Soft Snow}

Rammsonde: The Rammsonde, or Ram, hardness of snow is an indication of the resistance of snow to vertical penetration by a cone tip driven by the force of a weight dropped from a known height (Abele 1990). Ram hardness is significantly correlated with unconfined compressive strength (Abele 1963), shear strength (Abele 1968), and Ram hardness is linearly correlated with CBR (Abele 1990). Successive drops and notation of penetration distance can provide a profile of Ram hardness through the snow pack.

The Ram used in this study was equipped with a $30^{\circ}$ cone tip (2.4-cm [0.9-in.] diameter, 3.9-cm [1.5-in.] height, and 5-cm [2.0-in.] total length), typically used on groomed snow surfaces. Hammer weights ranging from 0.505 to $3.00 \mathrm{~kg}(1.1$ to $6.6 \mathrm{lb})$ were dropped from a height of 10 to $50-\mathrm{cm}$ (3.9 to $19.7-\mathrm{in}$.) to drive the $1.02 \mathrm{~kg}(2.2 \mathrm{lb})$ penetrometer into the snow surface. Drop weights and heights were adjusted to achieve penetrations less than $2 \mathrm{~cm}$ for each recorded interval, although this was usually not possible in the virgin snow. The Ram penetration resistance is reported as $R(\mathrm{kgf})$, and calculated based on the weight and drop height according to Abele (1990).

Yamaha Drop Cone: The Yamaha drop cone penetrometer, Figure 1, is an aluminum cone that is $9.82 \mathrm{~cm}$ (3.9 in.) tall, $19.88 \mathrm{~cm}$ (7.8 in.) in diameter, and weighs $1049 \mathrm{~g}(2.3$ lb). It is dropped from a $25.4 \mathrm{~cm}$ (10 in.) height above the snow into the ungroomed surface. The resulting depth of penetration into the snow is measured and used as a strength index.

Shear Vane: Measurements of surface shear strength were made using a Geonor H-60 hand-held vane tester (henceforth shear vane). The shear vane has an orthogonal, crossshaped blade. The standard vane blade and length comes in three sizes, and the size is chosen based on the snow strength. Custom vane sizes were also sometimes used. The vane is inserted into the snow to a depth covering the entire vane, and then a steady turning force is applied until the snow shears. The maximum shear force is recorded as kpa. Use of the shear vane in soils is covered by ASTM D2573-18 (ASTM 2018). 

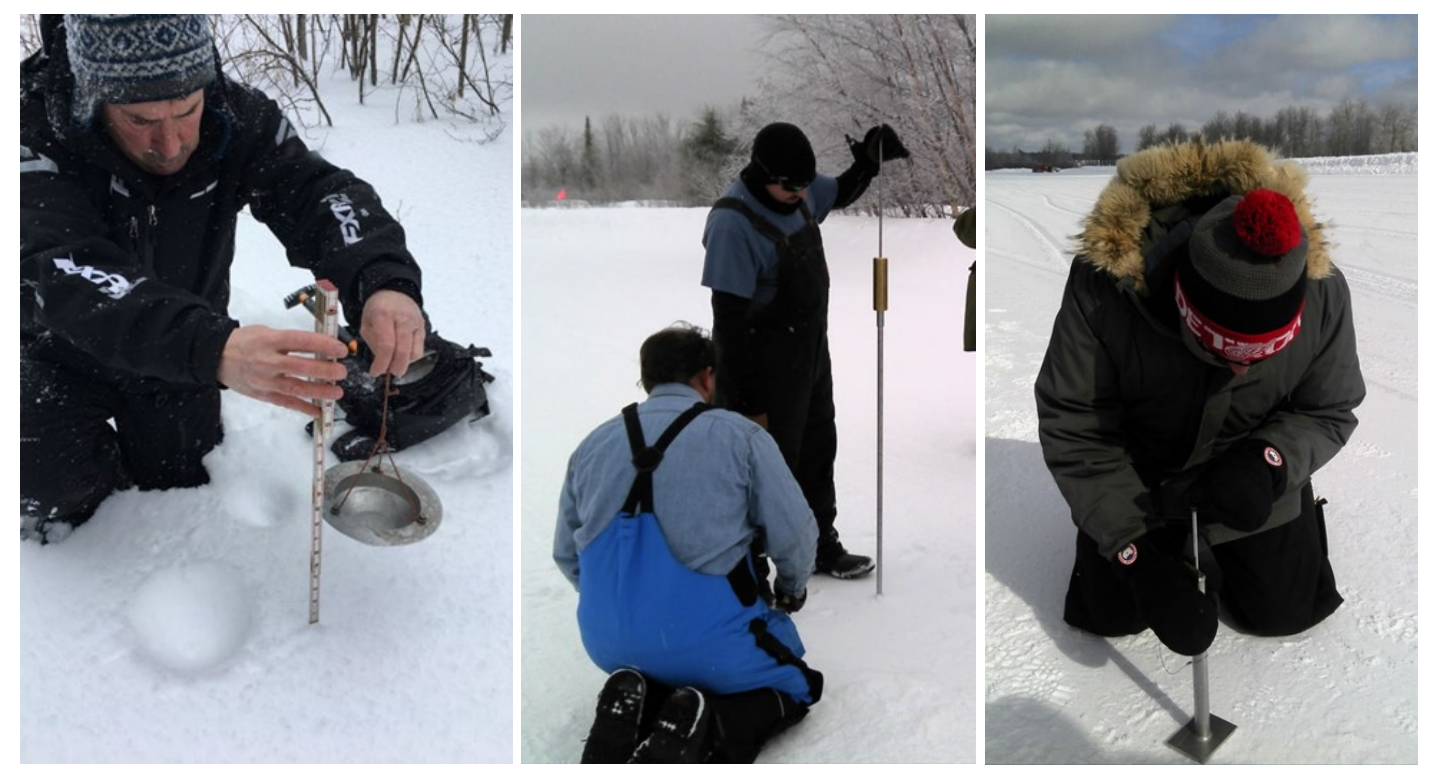

Figure 1. Yamaha drop cone (left), Rammsonde (middle), and CTI (right) tests in Michigan.

\subsection{Groomed Snow}

Field CBR: CBR, Figure 2, is a load-deformation test performed in the field or laboratory. The test was designed to provide results for use with empirical design charts to determine the design thicknesses for flexible pavements layers (i.e. asphalt concrete surface, aggregate base, and other layers.) for a given vehicle loading and number of passes. Current USACE, Navy, and U.S. Air Force design practice for surfaced and unsurfaced airfields is based on CBR (U.S. Army and Air Force 1994). The field CBR procedure is described in American Society for Testing and Materials (ASTM) D442909a, Standard Test Method for CBR (California Bearing Ratio) of Soils in Place (ASTM 2010), and Army Field Manual (FM) 5-530, Materials Testing (U.S. Army 1987).

LWD: The LWD, Figure 2, is a lighter, portable version of the Falling Weight Deflectometer (FWD). It was developed to estimate the in-situ stiffness modulus of soils. The device is typically used for quality control/quality assurance and evaluation of mechanically compacted earthwork and pavements (Senseney and Mooney 2010).

The Dynatest 3031 LWD device consisted of a $10 \mathrm{~kg}$ (22 lb) weight dropped from increasing heights along a guide rod. The weight makes contact with a rubber buffer, the load is transferred to the surface via a $300 \mathrm{~mm}$ (11.8 in.) diameter loading plate. The surface response from the load impact generates a vertical deflection response measured (through integration of velocity) by a centrally located geophone bearing on the loading plate (the annulus plug in the center of the plate was inserted for this work. The geophone reported deflection in mils. The LWD tests performed for this program typically had four drops at each of four heights (see also Wieder et al. 2019). 

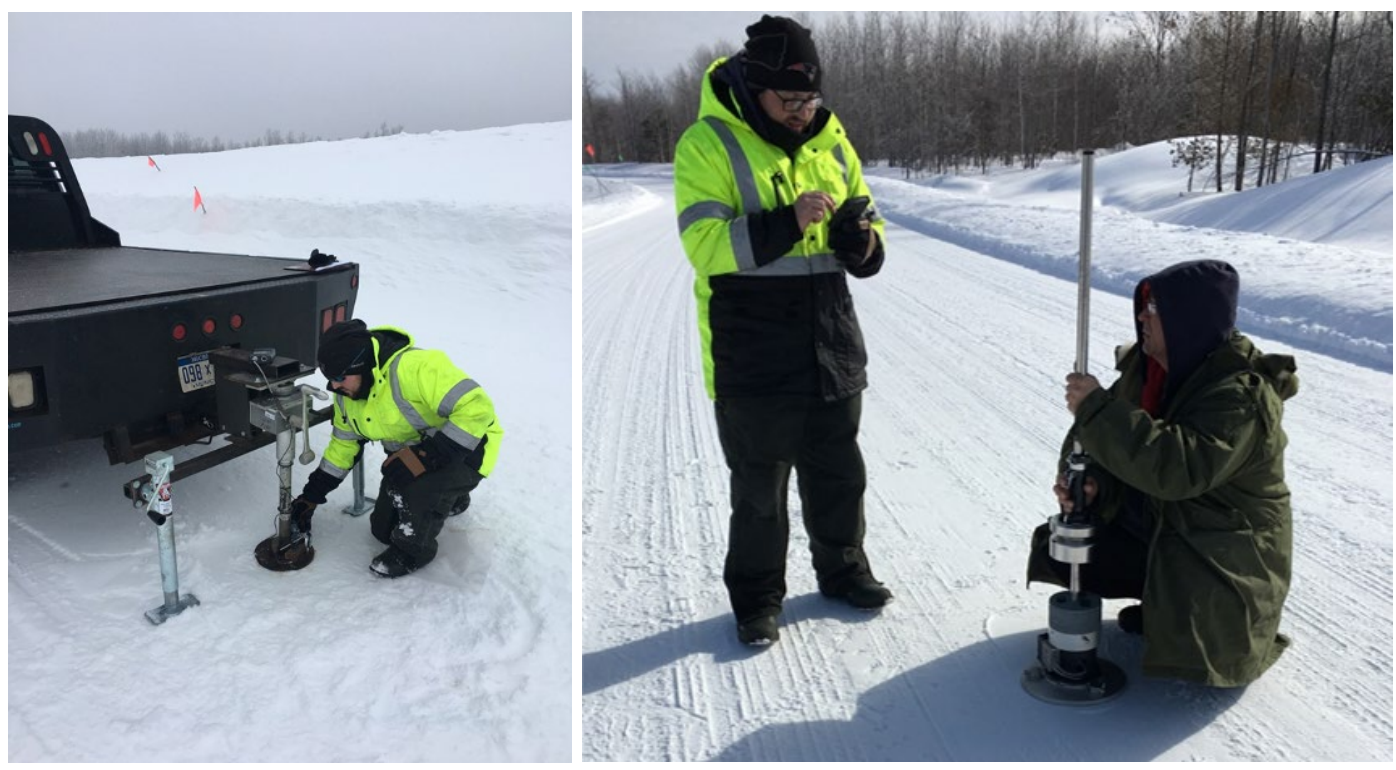

Figure 2. Field CBR (left) and LWD (right) tests Michigan.

Clegg Impact Hammers: The Clegg Impact Hammer consists of a cylindrical mass hammer that is dropped within a guide tube from a set height (Clegg 1980; ASTM 2016a). The hammer is equipped with an accelerometer that measures the peak deceleration on impact in $1 / 10$ gravity units. The hammer is dropped several times at each location, and deceleration readings are recorded for each drop. Typically, both the $2.25 \mathrm{~kg}(5.0 \mathrm{lb})$ and the $0.5 \mathrm{~kg}(1.1 \mathrm{lb})$ size Clegg hammers are used to measure natural ground surfaces. Shoop et al. (2012) provides a good summary and background on the different Clegg sizes, their uses, and conversion to other strength parameters.

Three Clegg measurements were taken at each measurement location using both the 2.25 $\mathrm{kg}$ hammer and the $0.5 \mathrm{~kg}(1.1 \mathrm{lb})$ hammer. Clegg Impact Values (CIVs) for each location were taken as the average of the third drop for the three measurements for the $2.25 \mathrm{~kg}(5.0 \mathrm{lb}) \mathrm{Clegg}$, and the fourth drop, for the $0.5 \mathrm{~kg}(1.1 \mathrm{lb})$ Clegg. CIVs were also converted to CBR using according to Shoop et al. (2012) and Millar (1977).

RSP: Though similar to the Ram in operation and hardness calculations, the RSP was designed for heavily compacted snow runways (Blaisdell et al., 1995). The RSP has a $30^{\circ}$ cone tip with maximum diameter of $1.15 \mathrm{~cm}(0.45 \mathrm{in}$.$) , and uses a 1.75 \mathrm{-kg}(3.9 \mathrm{lb})$ hammer dropped from a height of $50 \mathrm{~cm}(19.7$ in.) to drive a $1.421 \mathrm{~kg}(3.1 \mathrm{lb})$ penetrometer (with tip). In this study, RSP penetration depth was noted every 1-2 hammer blows, and ranged from 0 to $320 \mathrm{~mm}$ (0 to 12.6 in.) in depth.

CTI Penetrometer: The CTI snow compaction gauge, Figure 1, manufactured by Smithers Rapra, is shaped like a surveying plumb bob, attached to a rod with a total weight of $220 \pm 1 \mathrm{~g}(0.485 \pm 0.002 \mathrm{lb})$. The drop height is set to $218.9 \pm 0.25 \mathrm{~mm}(8.92 \pm$ 0.01 in.). The penetration distance is converted by a hand-held scale to read the compaction numbers of 50-100 on the CTI scale. The CTI is used for assessing the snow characteristics in commercial vehicle snow tire testing (ASTM 2016b). 


\section{ANALYSIS AND RESULTS}

The results of the testing were analyzed with the following objectives:

1. To assess the usefulness of the techniques in the various types of snow covers,

2. To measure typical strength values for the different types of snow covers,

3. To explore correlations between the snow strength parameters and other physical property measurements, and

4. To document the changes in snow strength with depth, before and after vehicle testing.

Preliminary results from objectives 1 to 3 are presented here. Further analysis of the strength, and how the snow and strength changes with the vehicle testing are on-going.

The strength tests tended to be better suited for either soft snow or groomed snow and none were effective under all conditions. An initial assessment of the effectiveness of each of the techniques for use on different types of snow and ice covers is given in Table 1. Some basic observations were:

- For groomed snow, the CBR, Clegg, RSP and CTI techniques worked best.

- For soft virgin snow, the Yamaha drop cone worked best but measures only the surface. The SMP worked very well for profile data in virgin snow (Meehan et al. 2019). The rammsonde sank through the snow without loading, so was ineffective for virgin snow.

- Nothing worked well on ice crusts or layers, except for very small tools not included here.

- The LWD may have an issue with testing at below freezing temperatures (see Menke et al. 2019).

- Both Clegg's were easy to use, and very efficient to operate in a timely manner.

- The Field CBR, though an Army standard, is cumbersome and time consuming to set up and run.

Figure 3 is a compilation of the strength measurements, snow depth, average density, and surface density (top $5 \mathrm{~cm}$ ) for the sites measured at Montana. Measurements were grouped into similar surface conditions. These plots illustrate the variability at each site and how the strength may be grouped and possibly estimated by surface type. Variability of surfaces could be due to several factors:

- Inherent variability of the snow itself.

- Variability of the ground surface beneath the snow, which could cause some areas to be more compacted than other during grooming.

- Variability in solar loading. Some points were in areas exposed to shade at certain times throughout the day.

- Elastic versus plastic behavior of groomed snow. In some cases the snow continued to compact under the test device (LWD, Clegg, CBR). For these tests, the initial measurements are indicative to the compaction of the initial snow conditions (a compactive material behavior), which subsequent loading would related better to repeated vehicle traffic of already compressed snow (an elastic material behavior). 
Table 1. Effectiveness rating matrix of field tests by operators $(1=\operatorname{good}, 5=\mathrm{bad})$.

\begin{tabular}{lcccccc}
\hline & \multicolumn{5}{c}{ Snow Surface Condition } \\
\hline Instrument & $\begin{array}{c}\text { Hard } \\
\text { Groomed } \\
\text { Snow }\end{array}$ & $\begin{array}{c}\text { Med } \\
\text { Groomed } \\
\text { Snow }\end{array}$ & $\begin{array}{c}\text { Fresh } \\
\text { Snow Over } \\
\text { Groomed }\end{array}$ & $\begin{array}{c}\text { Virgin } \\
\text { Snow }\end{array}$ & Wind Crust & $\begin{array}{c}\text { Ice or Ice } \\
\text { Layers }\end{array}$ \\
RSP & 3 & 2 & 3 or 4 & 3 or 4 & & NA \\
Field CBR & 1 & 1 & & NA & & \\
LWD & 1 & 2 & NA & NA & & 1 \\
2.25 kg Clegg & 4 & 4 & 1 & NA & & 2 \\
0.5 kg Clegg & 2 & 3 & 5 & NA & & NA \\
Shear Vane & 2 & 2 & 2 & 1 to 5 & & NA \\
Yamaha Drop Cone & 3 & 2 & 5 & $5 *$ & 5 & 5 \\
CTI & 5 & 3 & 2 & 1 & 3 & 4 \\
\hline
\end{tabular}

$\mathrm{NA}=$ Not applicable, indicating the instrument is unsuitable for this snow condition.

*Vane sizes were modified for virgin snow.

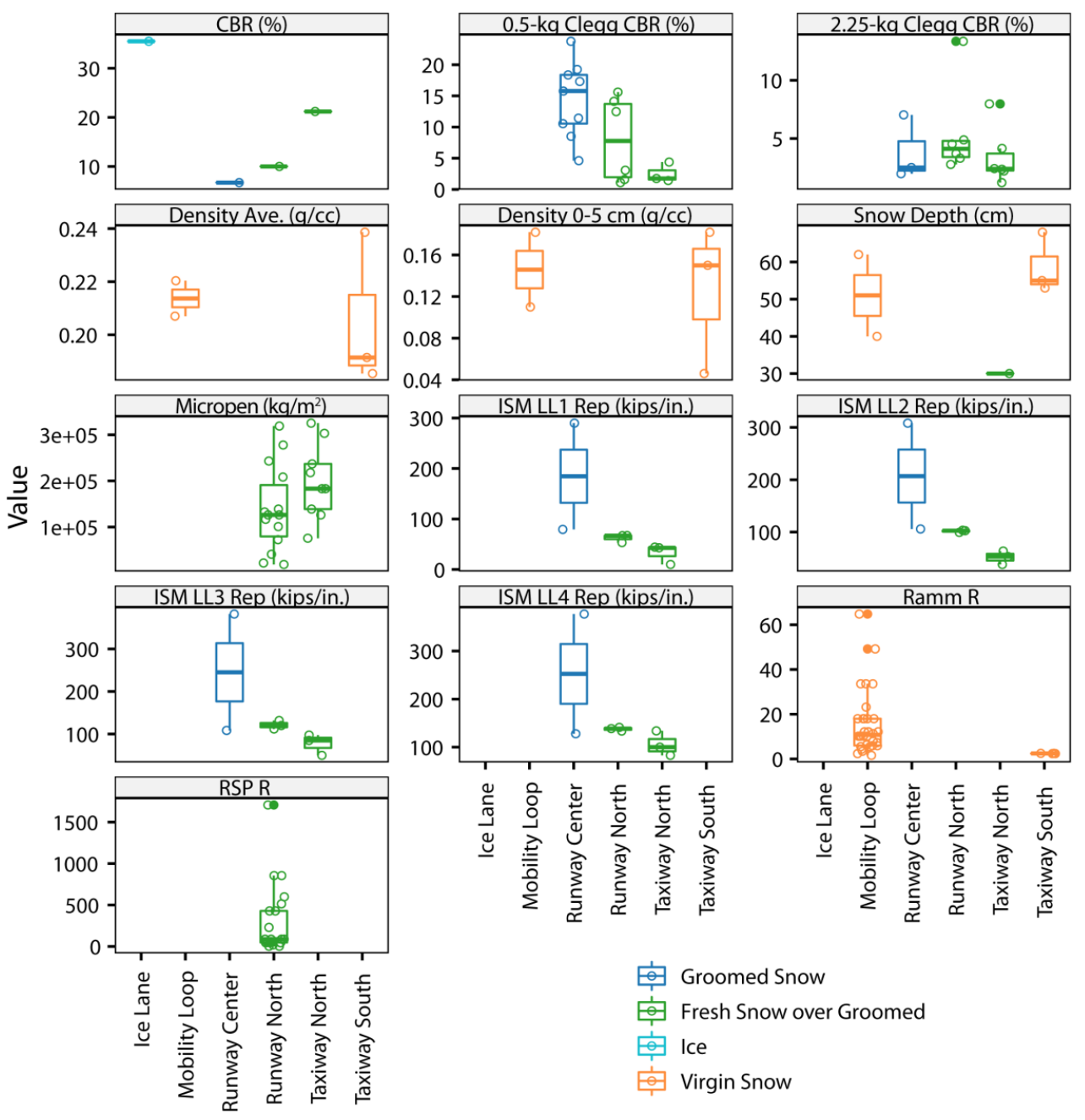

Figure 3. Boxplots of each measurement technique by study area in Montana. 
Strength of groomed snow surfaces: Field CBR measurements are used to compare insitu strength to design parameters for roads and airfields. This methodology is being replaced by mechanistic design methods but CBR design methods are still in use, especially for military airfields. True field CBR measurements are practically nonexistent for snow and ices surfaces and therefore were performed at both Montana and Michigan.

A summary of the CBR measurements by surface type for the Michigan site are given in Figure 4. Six test areas were measured: SpinUp2 (SU2), Loop 1 with grass substrate (LP1GS), Loop 1 with washed gravel substrate (LP1WG), SpinUp1 (SU1), the Sweeper Parking area (SWP), and SpinUp2 (SU3). The SpinUp areas are carefully and uniformly groomed, but the loops are subjected to vehicle test traffic. The parking area is subjected to more irregular grooming, vehicle traffic and equipment parking. For the most part, the field CBR values are consistent within each test surface except for the parking area and SU3. While you would expect the parking area to have a more variable surface, the reason for the variability in SU3 is unclear but could be due to variability in the subsurface conditions (Shoop et al. 2019). Analysis of the CBR data and is ongoing.

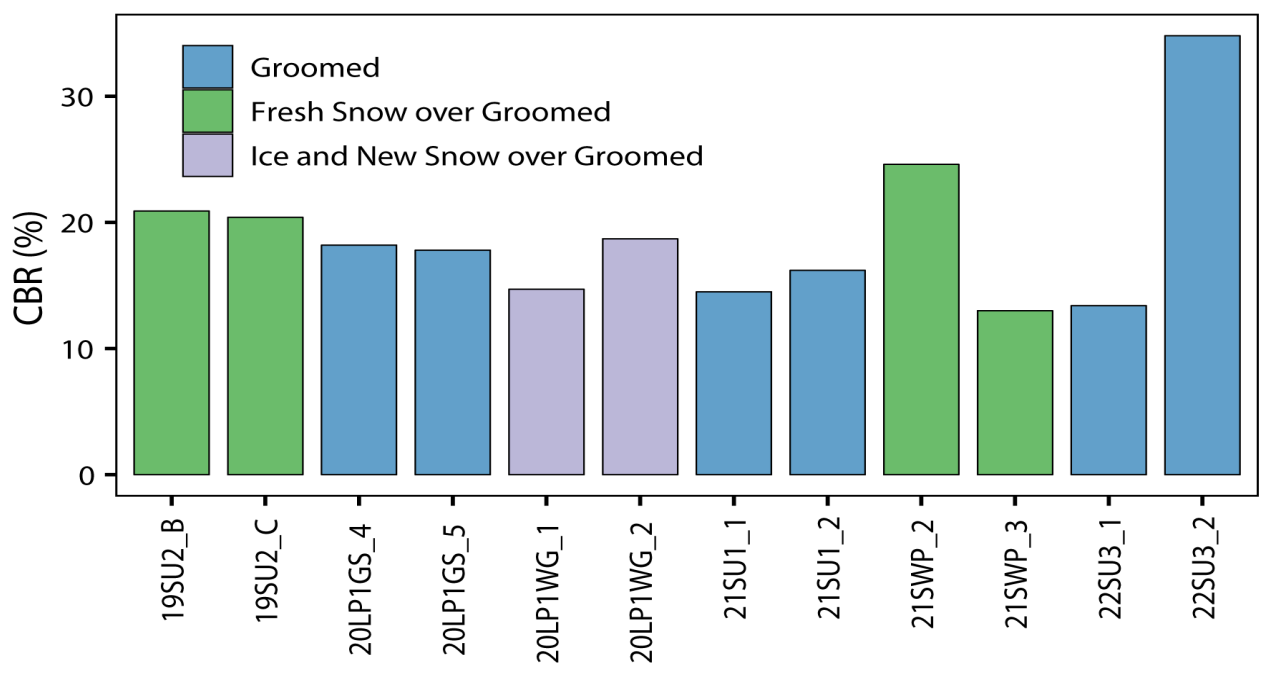

Figure 4. Field CBR by site in Michigan.

An efficient measurement of terrain strength that can also be correlated to CBR, is the Clegg Impact Hammer. This method has been used to assess snow road strength in Antarctica by Shoop et al. (2012). General strength measurements for many of the sites were measured using two different size Clegg Impact Hammers: $0.5 \mathrm{~kg}$ and $2.25 \mathrm{~kg}$. While the $0.5 \mathrm{~kg}$ hammer was useful for both the virgin and groomed snows, the $2.25 \mathrm{~kg}$ hammer was the most useful for a wide range of groomed snow surfaces (but not ice, which was out of the instrument range). The results for $2.25 \mathrm{~kg}$ Clegg measurements, converted to CBR, for the groomed snow surfaces Michigan are shown in Figure 5. The numerous surface types illustrate the variability of the Clegg CBR values for different types of snow surfaces, and the wide error bars illustrate the variability within a single type of snow surface. While most snow surfaces have strength values of less than 25 $\mathrm{CBR}$, a few measured values were higher, and even over $75 \mathrm{CBR}$. The highest values were likely within ruts, and this will be explored in the future. 
The LWD was also used on groomed snow but left significant indentations on many of the packed snow surfaces indicating it was continuing to compact the snow layer during the test sequence. For initial analysis with other strength data the impulse stiffness modulus (ISM), defined as the load divided by the deflection, at each load level (LL1 through LL4) was used. ISM is a parameter used for pavement evaluation by the U.S. Army and Air Force (USACE 2001) and the calculation does not use any assumptions about a seed modulus value or Poisson's ratio. The ISM values for all four load levels are shown in Figure 3. The LWD data is more thoroughly analyzed in Wieder et al. (2019) and the temperature effects on the LWD instrument were studied by Menke et al. (2019).

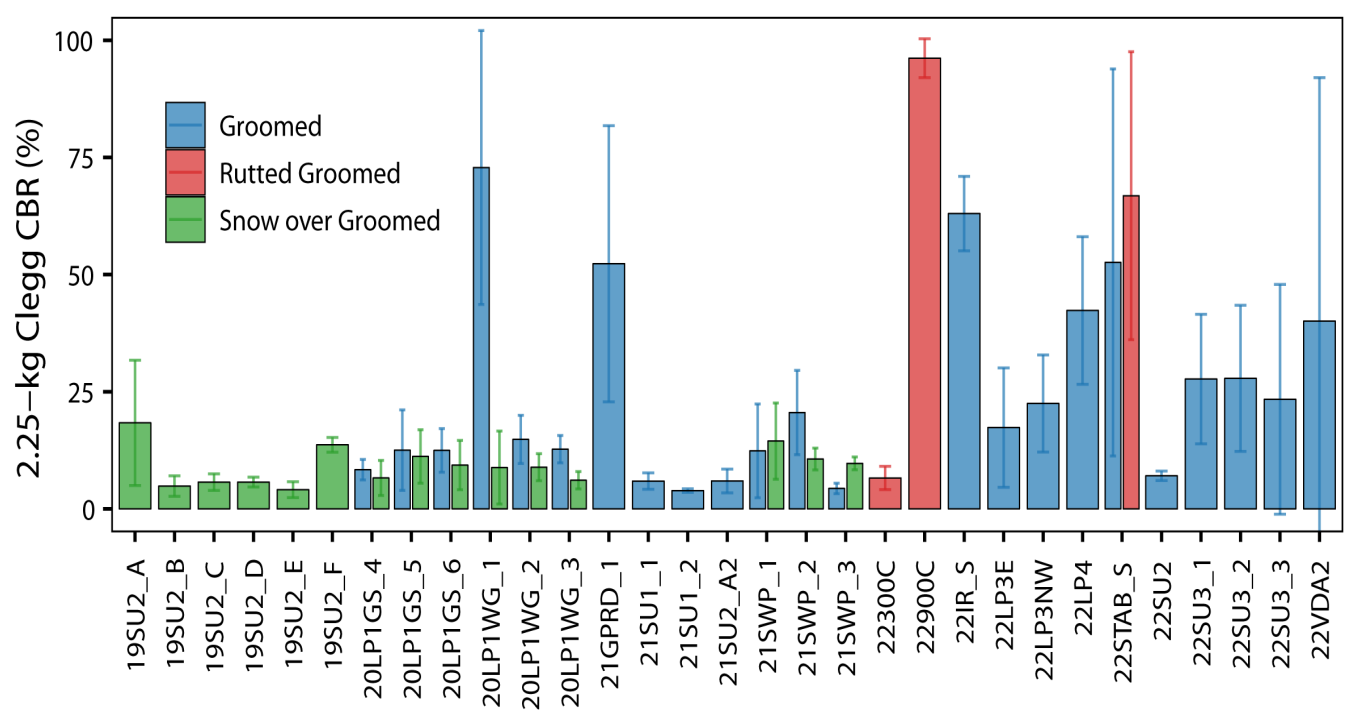

Figure 5. Mean site surface CBR calculated from 2.25 CIV, Michigan. Error bars are \pm one standard deviation.

Snow Strength Profile Data: Several of the snow measurements collect data within the snow cover as a function of depth (see Shoop et al. 2019). While the most basic of these are the snow density, moisture content, and temperature we also measured snow strength with depth using the Ram penetrometer and the RSP. Each of these instruments was designed for a specific application. The Ram was originally designed and used for snow roads and airfields in Antarctica and Greenland. The RSP was used by the Russians for their groomed snow runways. These are not necessarily well suited for reducing to a single number, as the benefit of the information is to capture the details of the snow profile. Often the profile data was sorted into layers for comparison with other measurements at the same depth. This analysis is on-going.

Correlations between strength measurements: The strength measurements were also evaluated to determine if they correlated with each other. No strong correlations were noted. However, specific correlations were also studied to calibrate strength measurements to the traditional field measured CBR. While most of these correlations are poor, a few were of note: 
- As expected, Clegg Impact Hammer trends with the CBR, showing higher values for the same surfaces.

- The CTI snow compaction gauge correlates with the $0.5 \mathrm{~kg}$ Clegg. Both are tools that are light and engage only near surface snow, generally for groomed surfaces.

- The RSP correlated with the $2.25 \mathrm{~kg}$ Clegg, both of which are tools for stronger surfaces (like snow roads and airfields).

\section{CONCLUSIONS}

This work aimed to evaluate methods to adequately characterize snow mechanical properties on a variety of snow types for air and ground vehicle entry and maneuver. Two field campaigns were used to do this, one in West Yellowstone, Montana in January 2018, and another in Calumet, Michigan in February 2018. Not all techniques were available at both sites, some techniques did not work in certain kinds of snow cover, and additional methods have since been identified for future studies.

Snow is extremely variable and its physical and mechanical properties can change drastically temporally and spatially, and perhaps most significantly with loading. This data collection included a wide range of snow types to assess which techniques worked best in specific conditions, and which techniques worked across the range of conditions. From these datasets and analysis, the mechanical measurements could be further grouped into 1) those that work well on groomed snow: CBR, $2.25 \mathrm{~kg}$ Clegg Impact Hammer, CTI and RSP; 2) those that work well on virgin snow: Yamaha drop cone, depth, density and moisture; 3) those that are best for profiling strength; Ram, and RSP; and 4) those that would specifically benefit from modifications for use in varied conditions: shear vanes.

Preliminary analyses of these results indicate some correlation between strength measures, especially when grouped based on the snow surface type. There remain many questions regarding the use of some of the more sophisticated measurements that have not previously been used in the cold or in snow. This field work provides a rich dataset of scientific snow characterization (stratigraphy, depth, density, moisture, etc.) and associated mechanical properties targeting both bearing capacity and shear strength measurements for evaluating and predicting strength for a variety of snow conditions. 


\section{REFERENCES}

Abele, G. (1963). A Correlation of Unconfined Compressive Strength and Ram Hardness of Processed Snow. TR 85. Hanover, NH: U.S. Army CRREL.

Abele, G. (1968). An Experimental Snow Runway Pavement in Antarctica. TR 211, Hanover, NH: U.S. Army CRREL.

Abele, G. (1990). Snow Roads and Runways. Monograph 90-3. Hanover, NH: U.S. Army CRREL.

ASTM. (2010). Standard Test Method for CBR (California Bearing Ratio) of Soils in Place. ASTM D4429-09a. Conshohocken, PA: ASTM International.

ASTM. (2016a). Standard Test Methods for Determination of the Impact Value (IV) of a Soil. ASTM D5874-16. Conshohocken, PA: ASTM International.

ASTM. (2018). Standard Test Method for Field Vane Shear Test in Saturated FineGrained Soils. ASTM D2573-18. Conshohocken, PA: ASTM International.

ASTM. (2016b). Standard Test Methods for Single Wheel Driving Traction in a Straight Line on Snow- and Ice-Covered Surfaces. ASTM F1805-16. Conshohocken, PA:

Blaisdell, G.L., Klokov, V., and Diemand, D. (1995). Compacted Snow Runway Technology on the Ross Ice Shelf Near McMurdo, Antarctica. Contributions to Antarctic Research IV, Antarctic Research Series, Vol. 67. Pp. 153-173.

Clegg, B. 1980. An Impact Soil Test as Alternative to California Bearing Ratio. In Proceedings, 3rd Australian-New Zealand (ANZ) Geomechanics Conference, Wellington, New Zealand, 1:225-230.

Elder, B., S. Shoop, M. Feyver, S. Beal (2019). Methods for Measuring Snow Moisture and Density. 18th International Conference on Cold Regions Engineering. Quebec, Canada, 18-22 August, 2019.

Meehan, T., H. P. Marshall, E. Deeb, S. Shoop (2019). SnowMicroPenetrometer Applications for Winter Vehicle Mobility. 18th International Conference on Cold Regions Engineering. Quebec, Canada, 18-22 August, 2019.

Menke, A., W. Wieder and S. Shoop (2019). Using the Light Weight Deflectometer in Winter Climates. 18th International Conference on Cold Regions Engineering. Quebec, Canada, 18-22 August, 2019.

Millar, L. R. (1977). Application of the Soil Impact Tester to Road Pavement Construction. Honours Thesis, Department of Civil Engineering, University of Western Australia, Crawley, Western Australia.

Senseney, C.T., Mooney, M.A. (2010). Characterization of Two-layer Soil System Using a Lightweight Deflectometer with Radial Sensors. Transportation Research Record: J. Transportation Research Board, No. 2186, Transportation Research Board of the National Academies. Washington, DC. pp. 21-28. DOI: 10.3141/2186-03.

Shoop, S. A., Crandell, J., and Knuth, M. (2012). Using a Clegg Impact Hammer to Measure Snow Strength. In Proceedings of the 15th International Conference on Cold Regions Engineering, Quebec, Canada, 19-22 August, 811-822.

Shoop, S.A., Wieder, W.L, Elder, B.C., Beal, S.A, and Deeb, E. (2019). Snow Mechanical and Spectral Characterization. ERDC/CRREL TR-19-XX. Hanover, NH: U.S. Army ERDC.

Sopher, A. and S. Shoop (2017). Stress Analysis of the Phoenix Compacted Snow Runway to Support Wheeled Aircraft. ASCE Cong, 10-13 September, 2017, Duluth, MN 
U.S. Army. (1987). Materials Testing. FM 5-530. Washington, DC: Dept. of the Army. U.S. Army and Air Force. (1994). Planning and Design of Roads, Airfield, and Heliports in the Theater of Operations-Road Design. FM 5-430-00-1/AFJPAM 32-8013, Vol.1. Washington, DC: Headquarters, Depts. of the Army and Air Force.

Wieder, W.L., Shoop, S.A. and Barna, L. (2019). Using the Light Weight Deflectometer to Assess Compacted Snow and Ice Surfaces. ERDC/CRREL TR-19-5. Hanover, NH: U.S. Army ERDC. 


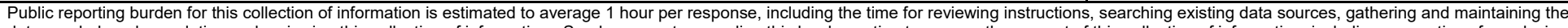

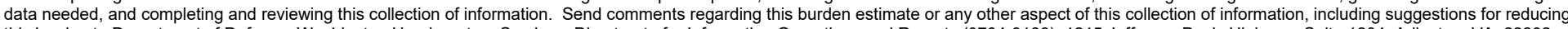

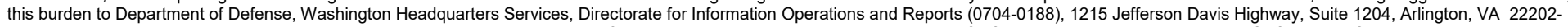

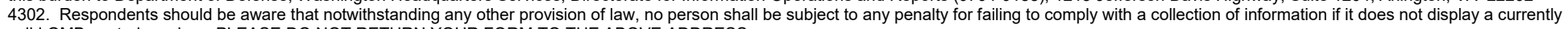
valid OMB control number. PLEASE DO NOT RETURN YOUR FORM TO THE ABOVE ADDRESS.
1. REPORT DATE (DD-MM-YYYY)
August 2020
2. REPORT TYPE
Final

4. TITLE AND SUBTITLE

Mechanical Property Measurements on Various Snow Surfaces

6. AUTHOR(S)

S. Shoop, W. Wieder, and B. Elder
3. DATES COVERED (From - To)

5a. CONTRACT NUMBER

5b. GRANT NUMBER

5c. PROGRAM ELEMENT NUMBER

5d. PROJECT NUMBER

465395

5e. TASK NUMBER

5f. WORK UNIT NUMBER

8. PERFORMING ORGANIZATION REPORT NUMBER

Cold Regions Research Laboratory

U.S. Army Engineer Research and Development Center

72 Lyme Road

ERDC/CRREL MP-20-6

Hanover, NH 03755

9. SPONSORING / MONITORING AGENCY NAME(S) AND ADDRESS(ES)

10. SPONSOR/MONITOR'S ACRONYM(S)

Assistant Secretary of the Army (AL\&T)

103 Pentagon

Washington, DC 20314

11. SPONSOR/MONITOR'S REPORT NUMBER(S)

\section{DISTRIBUTION / AVAILABILITY STATEMENT}

Approved for public release; distribution is unlimited.

\section{SUPPLEMENTARY NOTES}

Originally published in Proceedings of the 18th International Conference on Cold Regions Engineering and the 8th Canadian Permafrost Conference, 18-22 August 2019, Quebec City, Quebec, Canada.

\section{ABSTRACT}

During the winter of 2018 field experiments were conducted to assess the mechanical properties of virgin, groomed and compacted snow. These strength measurement techniques assessed the bearing and shear capacity of the snow, or a combination thereof. Many of the methods were adapted from those used in soil and pavement assessments and could be related to California Bearing Ratio; and others were techniques specifically designed for snow characterization (Rammsonde, Russian snow penetrometer, CTI penetrometer, Yamaha drop cone,). The results illustrate typical values and ranges for the strength of different types of snow surfaces, and the applicability or effectiveness of the different tests to specific snow conditions.

\section{SUBJECT TERMS}

Bearing, compacted, groomed, strength, winter

\begin{tabular}{|c|c|c|c|c|c|}
\hline \multicolumn{3}{|c|}{ 16. SECURITY CLASSIFICATION OF: } & 17. LIMITATION & 18. NUMBER & 19a. NAME OF RESPONSIBLE PERSON \\
\hline $\begin{array}{l}\text { a. REPORT } \\
\text { Unclassified }\end{array}$ & $\begin{array}{l}\text { b. ABSTRACT } \\
\text { Unclassified }\end{array}$ & $\begin{array}{l}\text { c. THIS PAGE } \\
\text { Unclassified }\end{array}$ & SAR & 15 & $\begin{array}{l}\text { 19b. TELEPHONE NUMBER } \\
\text { (include area code) }\end{array}$ \\
\hline
\end{tabular}

